EXPERIMENTAL STUDY

\title{
Co-localization of neuroendocrine hormones in the human fetal pancreas
}

\author{
Guida Maria Portela-Gomes ${ }^{1,4}$, Henry Johansson ${ }^{2}$, Lars Olding ${ }^{3}$ and Lars Grimelius ${ }^{1}$ \\ Departments of ${ }^{1}$ Pathology and ${ }^{2}$ Surgery, University Hospital, Uppsala, Sweden, ${ }^{3}$ Department of Pathology, Karolinska Institute at \\ Huddinge University Hospital, Stockholm, Sweden and ${ }^{4}$ Department of Medicine II, Gastroenterology Centre and Nutrition Centre, \\ University Hospital of Santa Maria, Lisbon, Portugal
}

(Correspondence should be addressed to G M Portela-Gomes, Department of Pathology, University Hospital, S-75185 Uppsala, Sweden; Fax: +46-18-502172)

\begin{abstract}
Objective and Design: Co-localization of the four major pancreatic hormones, and also of islet amyloid polypeptide (IAPP), peptide tyrosine tyrosine (PYY), secretin and neurotensin, has been studied in the endocrine pancreas of human fetuses at 16,18 and 22 weeks of gestation.

Methods: Double and triple immunofluorescence stainings have been used.

Results: All three fetal pancreata contained cells that showed insulin, glucagon, somatostatin, pancreatic polypeptide (PP), IAPP, secretin and PYY immunoreactivity. Neurotensin cells were found in the youngest fetus and gastric inhibitory polypeptide (GIP) in the two older fetuses. Colocalization of two hormones occurred in most of the endocrine cell types in the three fetuses examined, but three hormones occurred in only a few cells and especially in the youngest fetus. Somatostatin cells were the only cell type which was largely monohormonal. Our findings showed that there are two different co-localization patterns: insulin was co-localized mainly with IAPP and glucagon, while secretin and PYY occurred together with glucagon and PP.

Conclusions: These data are the first to describe secretin and neurotensin in the fetal pancreas. Two different co-localization patterns could be distinguished: insulin, IAPP and glucagon, and glucagon, secretin, PP and PYY.
\end{abstract}

European Journal of Endocrinology 141 526-533

\section{Introduction}

The adult endocrine pancreas synthesizes and releases four major hormones: insulin, glucagon, somatostatin and pancreatic polypeptide (PP). Islet amyloid polypeptide (IAPP), a recently discovered polypeptide with hormonal function, has been demonstrated in the endocrine pancreas, co-localized mainly with insulin (1). A small islet cell population has also been reported to show gastric inhibitory polypeptide (GIP) immunoreactivity (2).

The pancreas develops from two buds of the primitive foregut, one dorsal and one ventral, at the level of the bile duct (3). Earliest in the evolution among endocrine cells are the glucagon-immunoreactive (IR) cells, known from the incipient formation of the pancreatic buds, followed by insulin-IR $(4,5)$, somatostatin-IR and PP-IR cells, all four cell types being present by embryonic week (ew) 8 to 9 (6).

Studies on fetal porcine, murine and guinea-pig pancreas have shown that the endocrine progenitor cells can co-express more than one hormone $(7-11)$.
Corresponding studies on human pancreas are sparse, however, and have been performed with immuno-electronmicroscopic or immunofluorescence techniques. In the human fetal pancreas, cells coexpressing two $(8,12)$ or three of the four major pancreatic hormones have been described; a reduced frequency of co-localization was found with increasing fetal age $(13,14)$.

The aim of the present study was to demonstrate the co-localization not only of the four major islet hormones and IAPP but also special interest has been paid to other polypeptides not demonstrated in adult pancreas, such as peptide tyrosine tyrosine (PYY), secretin and neurotensin in the pancreas of fetuses in the second trimester, using single, double and triple immunofluorescence staining techniques.

\section{Materials and methods}

Pancreata from three human female fetuses obtained for routine histopathological examination in connection with autopsy examination were included in the study. 
The pregnancies had been terminated in ew 16, 18 and 22. Gestational age was determined by means of ultrasonic fetometry, direct fetometry and analysis of maternal menstrual regularity. The youngest fetus was from a prostaglandin-induced abortion necessitated by ultrasound findings of hygroma colli and hydrothorax, while the two older fetuses were from spontaneous abortions. The fetuses measured (crown-rump length) 12.0, 19.5 and $25.5 \mathrm{~cm}$ respectively, and their weights were 56,180 and $337 \mathrm{~g}$. Autopsy findings in the ew 16 fetus confirmed hygroma colli and hydrothorax; a malformed right ear and horseshoe kidney were also found; the other two fetuses displayed asphyxial haemorrhages in the lung due to placental ablation. None of the mothers had a history of diabetes mellitus. This study was approved by the Medical Ethics Committee at Huddinge Hospital, Stockholm.

The pancreatic specimens obtained were routinely fixed in $10 \%$ buffered neutral formalin for 18 to $20 \mathrm{~h}$ at room temperature (RT) and embedded in paraffin. Sections, $5 \mu \mathrm{m}$ thick, were cut and attached to poly-Llysine coated glass slides and stained with haematoxylineosin, or immunostained to demonstrate various hormones. The streptavidin-biotin complex (ABC) technique (15), with diaminobenzidine as chromogen, was applied as a single immunostain, mainly to reveal the distribution of endocrine cell types in the pancreas, but also for the control stainings mentioned below.

Immunofluorescence methods were used for single, double or triple staining, the latter two being applied to the same section to determine co-localization of different granular products. For triple immunofluorescence staining, the procedure was as follows: the sections were incubated with a cocktail of antibodies (one monoclonal+two polyclonal (anti-rabbit and antiguinea-pig)), overnight incubation at RT $\rightarrow$ biotinylated goat anti-guinea-pig immunoglobulin $\mathrm{G}(\operatorname{IgG}), 30 \mathrm{~min}$ at $\mathrm{RT} \rightarrow$ a mixture of fluorescein isothiocyanate (FITC)conjugated goat anti-rabbit IgG+Texas Red (TXRD)conjugated goat anti-mouse IgG+aminomethyl coumarin acetic acid (AMCA)-conjugated streptavidin, $30 \mathrm{~min}$ at RT. Double immunostaining was performed in the same way but with exclusion of one of the primary (and corresponding secondary) antibodies. The sections were rinsed thoroughly after each step in the staining procedure. Before applying the respective primary antibodies, the sections were incubated with nonimmune sera from the animal species producing the secondary antibodies.

The secondary antibodies were pre-incubated overnight with $10 \mu \mathrm{l} / \mathrm{ml}$ normal serum both from the species recognized by the other secondary antibodies and from the species donating the other secondary antibodies.

When two primary polyclonal antibodies raised in the same animal species (rabbit) were to be used, the staining procedure was as follows: initially the staining was performed with the first polyclonal antibody overnight at RT, followed by biotinylated swine anti-rabbit
IgG, 30 min at RT and TXRD-conjugated streptavidin, $30 \mathrm{~min}$ at RT. Thereafter the sections were exposed to paraformaldehyde vapour for $4 \mathrm{~h}$ at $80^{\circ} \mathrm{C}(16)$, then incubated with the second primary antibody overnight, followed by incubation with FITC- or AMCA-conjugated goat anti-rabbit IgG for $30 \mathrm{~min}$ at RT.

\section{Chemicals used}

The primary antibodies are characterized in Table 1. The labelled secondary antisera were: biotinylated goat anti-guinea-pig IgG, AMCA-labelled streptavidin (Vector Laboratories, Burlingame, CA, USA), TXRD-conjugated goat anti-mouse IgG (Southern Biotechnology Associates, Inc., Birmingham, AL, USA), FITC-conjugated goat anti-rabbit IgG (Sigma, St Louis, MO, USA). All antigens were purchased from Sigma, except porcine glucagon from Novo Nordisk A/S (Bagsvaerd, Denmark) and bovine glucagon from Lilly (Indianapolis, IN, USA).

The control stainings entailed (i) omission of the primary antibody or antibodies, (ii) replacement of the first layer of antibody by non-immune serum diluted 1:10 and by the diluent alone, and (iii) preincubation $(24 \mathrm{~h})$ of primary antibody with the corresponding or structurally related synthetic antigens (10 and $20 \mathrm{nmol}$ perml diluted antibody solution respectively) before application to the sections. These control tests were performed with $\mathrm{ABC}$ technique (single staining) and immunofluorescence (co-localization studies).

Particular attention was paid to the specificity tests on the secretin, glucagon, PP and PYY antibodies, to reveal any cross-reactivity. The secretin antibodies were preincubated with porcine secretin, porcine and bovine glucagon, human PP and porcine PYY antigens. Sections from human adult pancreatic islets were used as a positive control for glucagon antibodies and as a negative control for secretin antibodies. The neutralization tests with secretin antibodies and glucagon antigens were even performed in the pancreas of the ew 22 fetus. The PP antibodies were preincubated with PP, PYY, glucagon and secretin antigens, and the PYY antibodies with the PP, PYY and glucagon antigens. All control tests turned out as expected, i.e. no crossreaction was found between any of the antibodies. In double or triple immunofluorescence stainings, omission of one or two of the primary antibodies gave a staining result corresponding to the remaining primary antibody or antibodies.

The sections were examined in an Olympus Vanox AHBS3 fluorescence microscope (Olympus, Tokyo, Japan) equipped with filters (Olympus) giving excitation in wavelength bands of 475-555 nm for TXRD (filter no. 32821, dichroic mirror BH2-DMG), 453-488 nm for FITC (no. 32822, BH2-DMIB) and 340-375 nm for AMCA (no. 32817, BH2-DMU) respectively, while a double-band filter set (no. 39538, BH2-DFC5) for simultaneous visualization of TXRD- and FITC-labelled 
Table 1 Antisera used in this study.

\begin{tabular}{|c|c|c|c|c|}
\hline $\begin{array}{l}\text { Antibody raised } \\
\text { against }\end{array}$ & Code no. & $\begin{array}{l}\text { Directed } \\
\text { against }\end{array}$ & $\begin{array}{l}\text { Working } \\
\text { dilution* }\end{array}$ & Source \\
\hline Synthetic porcine GIP & B35-1 & - & $1: 80$ & Eurodiagnostica, Malmö, Sweden \\
\hline Synthetic human glucagon ${ }^{\mathrm{a}}$ & $\begin{array}{l}\text { Glu-001 } \\
7360061\end{array}$ & $\begin{array}{l}\text { Midportion } \\
(5-15)\end{array}$ & $1: 20$ & Novo Nordisk S/A, Bagsvaerd, Denmark \\
\hline Synthetic porcine glucagon ${ }^{b}$ & $\begin{array}{l}\text { A565 } \\
\text { lot } 081\end{array}$ & - & $1: 60$ & Dako Corp., Santa Barbara, CA, USA \\
\hline Purified porcine $^{1}$ glucagon $^{\mathrm{C}}$ & B-GP310-1 & & $1: 20$ & Eurodiagnostica \\
\hline Synthetic human insulin ${ }^{\mathrm{a}}$ & MUO $29 U C$ & A chain & $1: 80$ & $\begin{array}{l}\text { Biogenex Laboratories, San Ramon, } \\
\text { CA. USA }\end{array}$ \\
\hline Synthetic human insulin ${ }^{c}$ & Ma 47 & A chain & $1: 80$ & $\begin{array}{l}\text { Dr Per Westermark, Dept Pathology, } \\
\text { Linköping, Sweden }\end{array}$ \\
\hline Synthetic human IAPP & $\begin{array}{l}\text { RAS } 7321 \\
\text { lot } 21399-2\end{array}$ & - & $1: 200$ & $\begin{array}{l}\text { Peninsula Laboratories, Belmont, } \\
\text { CA, USA }\end{array}$ \\
\hline Synthetic neurotensin ${ }^{\mathrm{b}}$ & $6-8208$ & $\begin{array}{l}\text { C terminal } \\
(8-13)\end{array}$ & $1: 50$ & $\begin{array}{l}\text { Dr E Theodorsson, Dept Clinical Chemistry, } \\
\text { Linköping, Sweden }\end{array}$ \\
\hline Synthetic human PPb & $\begin{array}{l}\text { A619 } \\
\text { lot } 105\end{array}$ & - & $1: 50$ & Dako Corp. \\
\hline Synthetic porcine PYYc & B-GP520-1 & - & $1: 800$ & Eurodiagnostica \\
\hline Pure porcine secretin ${ }^{b}$ & B-33-1 & - & $1: 10$ & Eurodiagnostica \\
\hline Synthetic human somatostatin ${ }^{\mathrm{b}}$ & $\begin{array}{l}\text { A } 566 \\
\text { lot } 72\end{array}$ & $1-14$ & $1: 100$ & Dako Corp. \\
\hline Synthetic human somatostatin ${ }^{a}$ & Som-018 & $1-14$ & $1: 80$ & Novo Nordisk S/A \\
\hline
\end{tabular}

${ }^{a}$ Antisera raised in mouse (monoclonal); ${ }^{b}$ antisera raised in rabbit; ${ }^{c}$ antisera raised in guinea-pig. ${ }^{1}$ From Novo Nordisk S/A. * Dilutions used in immunofluorescence staining; for the ABC staining the dilutions were 10 to 20 times higher.

cells was also used (excitation at 550-570 $\mathrm{nm}$ and 480-495 nm respectively).

For triple immunofluorescence staining, all immunoreactive cells for the respective hormones were counted in three fields of vision at a magnification of $\times 400$, by changing the three different filters. The co-localization of hormones was expressed as a percentage of the total number of cells counted in each staining combination. Photomicrographs were taken using Fujicolor 800 film; the triple stainings were photographed by doubleexposing the film, first through the double-band and then with the AMCA filter sets.

\section{Results}

The endocrine pancreas of the ew 16 fetus consisted of mainly small, often irregular cell clumps connected with the ducts. In the ew 18 fetus the endocrine cells formed more distinct islets, but small cell clumps were still visible, as well as single cells among the exocrine parenchyma. In the oldest fetus (ew 22) most of the endocrine cells were found in the islets which were more distinctly delimited and more numerous.

\section{Immunoreactive cells}

All three fetal pancreata contained cells displaying insulin, glucagon, somatostatin, PP, IAPP, secretin and PYY immunoreactivity. A few weakly immunoreactive GIP cells were identified, present only in the two older fetuses. A few neurotensin-IR cells were observed in the youngest fetus. In the two older fetuses, glucagon-IR cells were apparently more numerous than PP-IR cells, while the youngest fetus contained a more or less equal number of these cell types.

In the youngest fetus, insulin-IR cells tended to be localized predominantly in small clumps, while in the two older fetuses, where islets had developed, these cells had a more central localization. Glucagon-IR cells had a greater tendency to a peripheral distribution in the cell clusters and in the islets. Somatostatin-IR cells were seen mainly in the periphery of the islets, except in the youngest fetus where they were mainly solitary and spread throughout the exocrine parenchyma. In the two younger fetuses the PP-IR cells were localized mostly in the small cell clumps and islets, with a varying distribution pattern; a few solitary cells were seen among the exocrine parenchymal cells. In the oldest fetus, PP cells were localized in the periphery of the islets. IAPP-IR cells had a distribution similar to that of the insulin-IR cells, while that of secretin-IR cells was more similar to the glucagon- and PP-IR cells. The few PYY-IR cells observed were solitary throughout the pancreas in all three fetuses.

\section{Co-localization of hormones}

The co-localization patterns are shown in Table 2. Colocalization of two hormones occurred in most of the endocrine cell types in all three fetuses examined. Somatostatin-IR cells were the only cell type which was largely monohormonal. The frequency of cells expressing co-localization of hormones was highest in the ew 16 fetus; on the whole, co-localization decreased with age. 
Table 2 Co-localization of hormones in three human fetuses, embryonic weeks 16, 18 and 22, expressed as a percentage of the total number of cells counted by double or triple staining, by using different filters. The figures within parentheses refer to the total number of cells in each staining combination, i.e. those cells immunostained solely by the first primary antibody, plus those stained solely by the second primary antibody, plus those showing double or triple staining.

\begin{tabular}{|c|c|c|c|c|c|c|}
\hline \multirow[b]{3}{*}{ Hormones } & \multicolumn{6}{|c|}{ (Percentage of co-localized cells) } \\
\hline & \multicolumn{2}{|c|}{16 weeks } & \multicolumn{2}{|c|}{18 weeks } & \multicolumn{2}{|c|}{22 weeks } \\
\hline & $\%$ & $(n)$ & $\%$ & $(n)$ & $\%$ & $(n)$ \\
\hline Insulin + glucagon & 8.3 & $(124)$ & 8.1 & $(605)$ & 1.5 & $(543)$ \\
\hline Insulin + somatostatin & 1.1 & (190) & 2.5 & (290) & 2.1 & $(381)$ \\
\hline Insulin + PP & 6.2 & (283) & 1.5 & (387) & 0.6 & (355) \\
\hline Insulin + IAPP & 18.8 & $(112)$ & 16.4 & (404) & 49.5 & (297) \\
\hline Insulin + secretin & 0 & & 0 & & 0 & \\
\hline Insulin + PYY & 0 & & 0 & & 0 & \\
\hline Glucagon + somatostatin & 3.8 & $(258)$ & 1.6 & $(418)$ & 1.1 & $(345)$ \\
\hline Glucagon + PP & 47.4 & (233) & 7.2 & (290) & 1.4 & (179) \\
\hline Glucagon + IAPP & 7.2 & (129) & 72.5 & (379) & 35.6 & (326) \\
\hline Glucagon + secretin & 67.3 & (49) & 100 & (88) & 100 & $(86)$ \\
\hline Glucagon + PYY & 1.6 & (129) & 0.8 & (237) & 0 & \\
\hline Glucagon + neurotensin & few & & 0 & & 0 & \\
\hline Somatostatin + PP & 3.6 & $(302)$ & 3.4 & $(296)$ & 2.1 & $(235)$ \\
\hline Somatostatin + IAPP & 1.1 & $(92)$ & 4.3 & $(161)$ & 2.6 & (156) \\
\hline Somatostatin + secretin & 0 & & 0 & & 0 & \\
\hline Somatostatin + PYY & 0 & & 0 & & 0 & \\
\hline$P P+I A P P$ & NE & & $\mathrm{NE}$ & & $\mathrm{NE}$ & \\
\hline$P P+$ secretin & 92.9 & $(56)$ & 20.6 & (34) & 68.8 & (26) \\
\hline$P P+P Y Y$ & 41.9 & (31) & 14.7 & (34) & 5.3 & (29) \\
\hline Insulin + glucagon + somatostatin & 0 & (83) & 0 & $(216)$ & 0 & $(219)$ \\
\hline Insulin + glucagon + PP & 1.5 & (133) & 0.5 & $(185)$ & 0 & (194) \\
\hline Insulin + somatostatin + PP & 0.4 & $(210)$ & 0 & $(270)$ & 0 & (236) \\
\hline Glucagon + somatostatin + PP & 1.0 & (203) & 0.6 & $(161)$ & 0 & (181) \\
\hline IAPP + insulin + glucagon & 1.8 & $(147)$ & 0.2 & $(458)$ & 0.8 & (132) \\
\hline IAPP + glucagon + somatostatin & 0.9 & $(109)$ & 0.5 & $(214)$ & 0 & $(159)$ \\
\hline
\end{tabular}

NE, not estimated.

The various hormones in the endocrine pancreas occurred in different combinations, the most frequent being glucagon with secretin (Fig. 1, 1A and 1B), followed by $\mathrm{PP}$ with secretin (Fig. 1, $2 \mathrm{~A}$ and $2 \mathrm{~B}$ ), except in the ew 18 fetus. Other hormones with a high percentage of co-localization were glucagon with IAPP (Fig. 1, 3A and 3D), insulin with IAPP (Fig. 1, 3B, 3D, 4A and 4B), and PP with PYY. The other co-localization combinations occurred only in small cell populations (Fig. 1, 5A-5D).
Triple co-localization occurred in just a few cell clumps (Fig. 1, 3A-D). Neurotensin was demonstrated in the ew 16 fetus and was found to be co-localized with glucagon (Fig. 1, 6A-6C) but not with insulin.

\section{Discussion}

Few ontogenic studies of endocrine fetal pancreas are performed on humans due to problems in obtaining

Figure 1 (1A and 1B) Human fetal pancreas (ew 18) double-stained for (1A) glucagon (FITC), and (1B) secretin (Texas Red). All the immunostained cells show co-localization of these two hormones. (2A and 2B) Human fetal pancreas (ew 16) double-stained for (2A) PP (FITC), and (2B) secretin (Texas Red). The same cells display both immunoreactivities. Bar $(1 \mathrm{~A}-2 \mathrm{~B})=48 \mu \mathrm{m}$. (3A-3D) Human fetal pancreas (ew 18) triple-stained for (3A) glucagon (FITC), (3B) insulin (Texas Red), and (3D) IAPP (AMCA). Glucagon and insulin appear in different cells with one exception, seen as yellow with the double-band filter (3C); this cell also contains IAPP, i.e. shows triple hormonal colocalization. IAPP occurs in all the glucagon cells and in a few insulin cells. Bar $=18 \mu \mathrm{m}$. (4A-4C) Human fetal pancreas (ew 22) doublestained for (4A) insulin (FITC), and (4B) IAPP. All the cells immunostained for insulin show co-localization with IAPP, as illustrated by the yellow colour visualized with the double-band filter set (4C), but IAPP also occurs in non-insulin cells. Bar $=24 \mu \mathrm{m}$. (5A-5D) Human fetal pancreas (ew 16) triple-stained for (5A) PP (FITC), (5B) somatostatin (Texas Red), and (5D) insulin (AMCA). There is co-localization of PP and somatostatin in a few cells only, illustrated as yellow with the double-band filter (5C). Some of the insulin cells also display PP immunoreactivity (arrows). Bar $=24 \mu \mathrm{m}$. (6A-6C) Human fetal pancreas (ew 16) double-stained for (6A) neurotensin (FITC), and (6B) glucagon (Texas Red). In a few cells, distinct co-localization of these two polypeptides is visualized as yellow with the double-band filter set (6C). $\mathrm{Bar}=48 \mu \mathrm{m}$. 


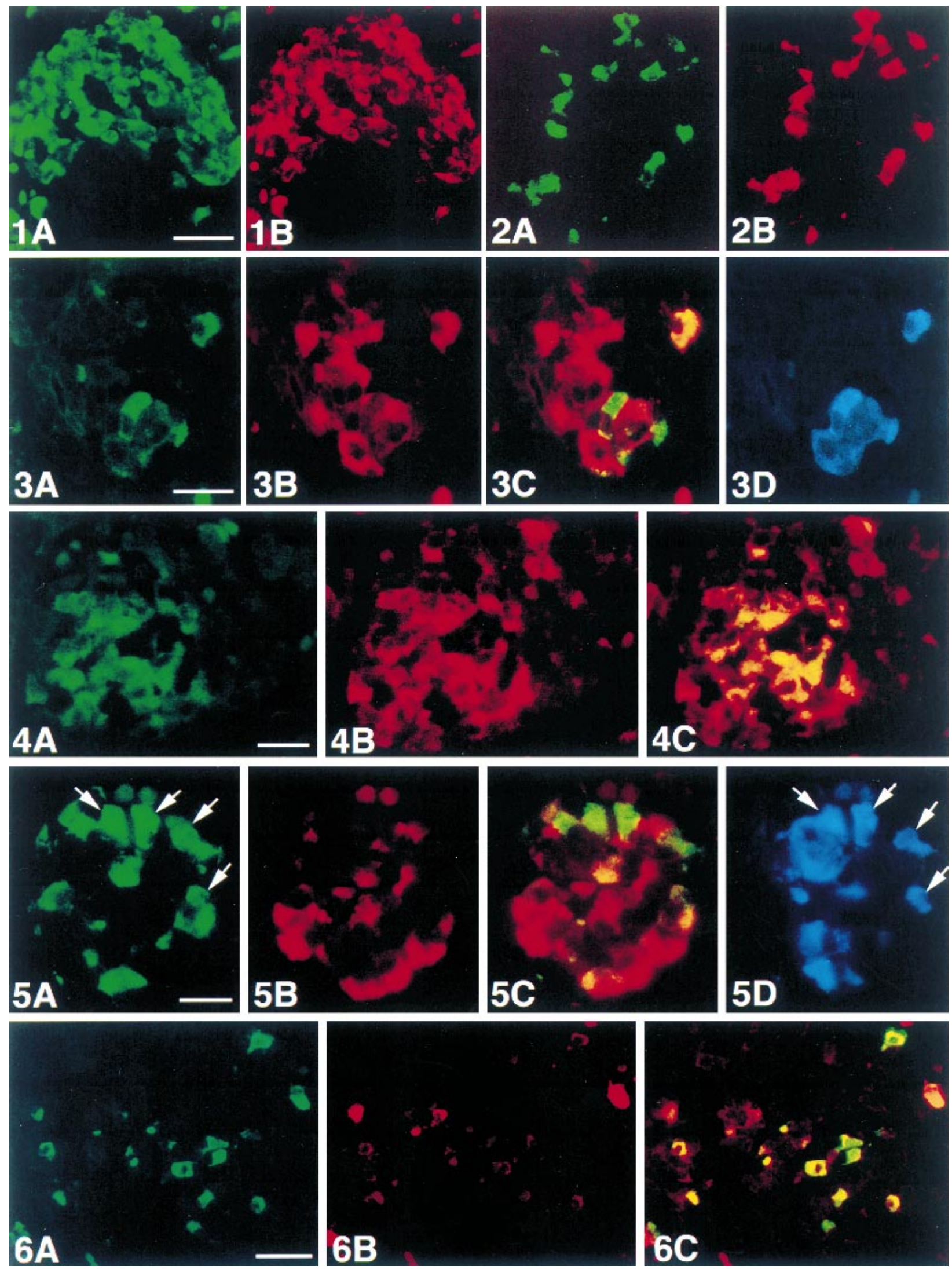


proper tissue material. For obvious reasons the material was also limited in number in the present study. Due to the small size of the pancreata no systemic randomization of the histological sections in each staining combination was performed, but the staining technique in itself, with single, double and triple stainings in serial sections implies a form of randomization. The main purpose of this study was to investigate the colocalization of the four major islet hormones, IAPP and other polypeptides not demonstrated in adult pancreas.

It is well known that the islet cell composition varies in different parts of the pancreas, where the processus uncinatus developing from the ventral anlage contains a large proportion of PP cells and few glucagon cells, while the converse is the case in the remaining pancreas. As only archival material has been available, we were not able to separate the processus uncinatus from the remaining gland. As pancreata from the two older fetuses contained few PP cells and a relatively large proportion of glucagon cells, our sections probably represented the body-tail region. In the pancreas from the youngest fetus the PP and glucagon cells appeared to be more or less equal in number, which indicates that these glandular sections also included the processus uncinatus.

The present study demonstrated the occurrence of secretin, neurotensin, PYY, GIP and IAPP in fetal pancreas, besides the four classical hormones. Secretin and neurotensin, not present in the adult pancreas, are here reported for the first time, whereas the presence of the other hormones confirms previous findings.

In the present study numerous secretin-IR cells were seen in fetal pancreas. Moreover, the high content of secretin-IR cells in the fetus suggests that secretin may play a functional role in fetal development. Secretin and glucagon, which belong to the same peptide family and display quite considerable amino acid sequence homology, were often co-localized. Our secretin antibodies were raised against pure porcine secretin (Prof. V Mutt, Karolinska Institute, Stockholm, Sweden) and our extensive control tests on the secretin antibodies revealed no signs of cross-reactivity with glucagon. An explanation for this co-localization pattern could be that they share a common molecular precursor. Our findings corroborate the genetic relationship of secretin with glucagon suggested by studies in transgenic mice expressing the simian virus 40 oncoprotein large Tantigen (Tag), controlled by the secretin gene, which developed glucagon-producing endocrine tumours in the colon (17). Besides glucagon, secretin was also colocalized with PP. These two polypeptides do not share any amino acid sequence homology and our control tests did not show any antibody cross-reactivity. Some of these PP cells most probably also contain glucagon. The higher frequency of $\mathrm{PP} /$ secretin cells compared with glucagon/secretin cells indicates that there are cells that contain PP but not glucagon. These findings point to the possibility that secretin can also arise in the absence of a glucagon-secretin precursor.

In contrast to the numerous secretin cells, the other newly detected polypeptide, neurotensin, was found in small amounts, only in glucagon cells and only in early fetal age. The importance of neurotensin in the fetal pancreas is unclear, but a growth factor function has been suggested in the pancreas and intestinal tract (18).

The co-localization of PYY and glucagon agrees with findings by Ali-Rachedi et al. (12) in the human fetal pancreas and by Upchurch et al. (11) and Jackerott et al. (19) in mice. Co-localization of PYY and glucagonrelated peptides has also been reported in adult human intestinal mucosa. However, in contrast to Ali-Rachedi et al. (12) we also found PP co-localized with PYY. Although PYY-IR cells occurred in small numbers, decreasing with fetal age, our finding suggests that PYY plays a role in the early development of the pancreas.

The finding of GIP-IR cells in fetal pancreas agrees with a previous report (20). Co-localization studies on GIP were not performed in the present investigation due to lack of material. However, GIP has been reported in glucagon cells in both adult and fetal human endocrine pancreas $(2,21)$. Although both these peptides belong to the same family, our control tests in adult pancreas suggest that there is no mutual cross-reactivity.

The finding of co-localization of insulin and IAPP agrees with previous reports $(1,22,23)$. These results corroborate the attributed functional relationship between these two polypeptides in response to glucose stimulus, as reported by Rindi et al. (1). However, IAPP was found not only in insulin cells, but also in varying numbers of glucagon cells, which is consistent with the findings of Lukinius et al. (23) in their ew 14 fetus. This latter report also describes co-localization of IAPP with somatostatin, a finding which we were able to confirm. In agreement with other observations, insulin was also found together with glucagon immunoreactivity $(8,13$, 14). Furthermore, these two immunoreactive polypeptides have been found in the same secretory granules $(8,13)$. In vitro studies have also suggested a functional relationship between insulin and glucagon, as glucagon seems to be a potent stimulus of insulin release $(24,25)$.

Only a small number of somatostatin cells displayed co-localization with either insulin or glucagon, but such co-localization is in agreement with other reports $(8,13)$, although we have shown a smaller number of somatostatin cells displaying insulin immunoreactivity than previously described; in a few cells, somatostatin and PP were co-localized in all three fetuses, a finding not reported earlier in humans. Our findings do suggest, however, that somatostatin cells are to a large extent monohormonal, possibly because somatostatin cells may derive from a different precursor cell lineage.

Knowledge of the physiological significance of polypeptides during fetal development is limited. Evidence that regulatory peptides in the animal fetus are released 
has only been shown for gastrin, PP and GIP $(26,27)$. The differences in frequency of co-localization of the various polypeptides at different fetal ages suggest that they have a regulatory role also in human. It is possible that various peptides may be involved in fetal metabolism or may exert regulatory actions and/or interactions in the complex growth and differentiation of the developing pancreas (28). In this sense, somatostatin and PYY have been reported to have growth inhibitory effects $(29,30)$, while neurotensin seems to induce pancreatic growth (18). However, it remains to be proved if these growth effects are valid for the fetus as it has been shown that peptide actions in the animal fetus can differ from those in the adult (31).

The development of the fetal endocrine pancreas appears to undergo three phases: (i) from ew 10 to 15 , when the endocrine cells start to form distinct islets, (ii) from ew 16 to 20, when the islets acquire their characteristic vascular system, and (iii) from ew 21 to 26 when the islet innervation is developed (32). Of the present cases, two are included in the mid phase and one in the last. A recent study (33) showed the highest proliferation rate of the endocrine pancreas to occur at ew 10 and during ew 14 to 16 . This is coincident with the highest co-localization of hormones found in the present study.

The reason for the varying co-localization pattern of polypeptides in the fetal pancreatic endocrine cells is also still unclear. Based on co-localization studies in an insulin-Tag transgenic mouse model, Alpert et al. (34) proposed the hypothesis that the four major pancreatic endocrine cells must derive from a progenitor stem cell line displaying glucagon immunoreactivity. In agreement with previous ultrastructural studies, the present findings showed that glucagon was co-localized with all the other hormones examined, which supports, but does not prove, this hypothesis $(8,13,23)$. Recent studies on transcriptional regulation of rat pancreatic endocrine cells suggest, however, that insulin cells do not derive from a glucagon progenitor cell (35-38).

In conclusion, our study has shown that the human fetal pancreas expresses secretin and neurotensin, as well as the previously reported polypeptides PYY, GIP and IAPP, besides the four classical hormones. A complex co-localization pattern of polypeptide hormones was found, except for somatostatin, which was mostly monohormonal. Co-localization of three hormones was rare. Two different co-localization patterns could be distinguished: (i) insulin, IAPP and glucagon, and (ii) glucagon, secretin, PP and PYY.

\section{Acknowledgements}

This work was supported by a grant from the Swedish Medical Research Council (no. 102) and Familjen Ernfors' Foundation, Sweden. We thank Ms Birgitta Vagnhammar for excellent technical assistance.

\section{References}

1 Rindi G, Terenghi G, Westermark G, Westermark P, Moscoso G \& Polak JM. Islet amyloid polypeptide in proliferating pancreatic B cells during development, hyperplasia, and neoplasia in humans and mice. American Journal of Pathology 1991138 1321-1334.

2 Alumets J, Håkanson R, O'Dorisio T, Sjölund K \& Sundler F. Is GIP a glucagon cell constituent? Histochemistry 197858 253-257.

3 Pictet R \& Rutter WJ. Development of the embryonic pancreas. In Handbook of Physiology, section 7, Endocrinology, vol.1, Endocrine Pancreas, pp 25-66. Eds DF Steiner \& N Freinkel. Washington: American Physiological Society, 1972.

4 Stefan Y, Grasso S, Perrelet A \& Orci L. A quantitative immunofluorescent study of the endocrine cell populations in the developing human pancreas. Diabetes 198332 293-301.

5 Tornehave D, Jansen P, Teisner B, Rasmussen HB, Chemnitz J \& Moscoso G. Fetal antigen (FA1) in the human pancreas: cell type expression, topological and quantitative variations during development. Anatomy and Embryology 1993187 335-341.

6 Fuji S. Development of pancreatic endocrine cells in the rat fetus. Archivum Histologicum Japonicum 197942 467-479.

7 Hashimoto T, Kawano H, Daikoku S, Shima K, Taniguchi H \& Baba S. Transient coappearance of glucagon and insulin in the progenitor cells of the rat pancreatic islets. Anatomy and Embryology 1988178 489-497.

8 Lukinius A, Ericsson JL, Grimelius L \& Korsgren O. Ultrastructural studies of the ontogeny of fetal human and porcine endocrine pancreas, with special reference to colocalization of the four major islet hormones. Developmental Biology $1992153376-385$.

9 Reddy S, Bibby NJ \& Elliott RB. An immunocytochemical study of endocrine cell development in the early fetal guinea-pig pancreas. General and Comparative Endocrinology 199286 275-283.

10 Teitelman G, Alpert S, Polak JM, Martinez A \& Hanahan D. Precursor cells of mouse endocrine pancreas coexpress insulin, glucagon and the neuronal proteins tyrosine hydroxylase and neuropeptide Y, but not pancreatic polypeptide. Development 1993 118 1031-1039.

11 Upchurch BH, Aponte GW \& Leiter AB. Expression of peptide YY in all four islet cell types in the developing mouse pancreas suggests a common peptide YY-producing progenitor. Development $1994120245-252$.

12 Ali-Rachedi A, Varndell I, Adrian T, Gapp D, Van Noorden S, Bloom S et al. Peptide YY (PYY) immunoreactivity is co-stored with glucagon-related immunoreactants in endocrine cells of the gut and pancreas. Histochemistry $198480487-491$.

13 De-Krijger RR, Aanstoot HJ, Kranenburg G, Reinhard M, Visser WJ \& Bruining GJ. The midgestational human fetal pancreas contains cells coexpressing islet hormones. Developmental Biology 1992 $153368-375$.

14 Larsson L-I \& Hougaard DM. Coexpression of islet hormones and messenger RNAs in the human foetal pancreas. Endocrine 19942 $759-765$.

15 Hsu SM, Raine T \& Fanger H. Use of avidin-biotin-peroxidase complex $(\mathrm{ABC})$ in immunoperoxidase techniques: a comparison between $\mathrm{ABC}$ and unlabeled (PAP) procedures. Journal of Histochemistry and Cytochemistry 198129 577-580.

16 Wang B-L \& Larsson L-I. Simultaneous demonstration of multiple antigens by indirect immunofluorescence or immunogold staining. Histochemistry 198583 47-56.

17 Lopez MJ, Upchurch BH, Rindi C \& Leiter AB. Studies in transgenic mice reveal potential relationships between secretin-producing cells and other endocrine cell types. Journal of Biological Chemistry $1995270885-891$.

18 Feurle GE, Muller B \& Rix E. Neurotensin induces hyperplasia of the pancreas and growth of the gastric antrum in rats. Gut 1987 28 (Suppl. 1) 19-23.

19 Jackerott M, Oster A \& Larsson L-I. PYY in developing murine islet cells: comparisons to development of islet hormones, NPY, and brdU incorporation. Journal of Histochemistry and Cytochemistry $199644809-817$. 
20 El-Salhy M, Wilander E \& Grimelius L. Immunocytochemica localization of gastric inhibitory peptide (GIP) in the human foeta pancreas. Uppsala Journal of Medical Sciences 198287 81-85.

21 Leduque P, Gespach C, Brown JC, Rosselin G \& Dubois PM. Ontogeny of gastric inhibitory peptide in the human gastrointestinal tract and endocrine pancreas. Acta Endocrinologica $198299112-121$.

22 In't Veld PA, Zhang F, Madsen OD \& Klöppel G. Islet amyloid polypeptide immunoreactivity in the human fetal pancreas. Diabetologia $199235272-276$.

23 Lukinius A, Korsgren O, Grimelius L \& Wilander E. Expression of islet amyloid polypeptide in fetal and adult porcine and human pancreatic islet cells. Endocrinology 1996137 5319-5325.

24 Hayek A \& Guardian C. Hormone release, islet yield, and transplantation of fetal and neonatal rat dorsal and ventral pancreatic islets. Diabetes 198635 1189-1195.

25 Otonkoski T. Insulin and glucagon secretory responses to arginine, glucagon and theophylline during perfusion of human fetal islet-like cell clusters. Journal of Clinical Endocrinology and Metabolism 198867 734-740.

26 Sangild PT, Hilsted L, Bjørnskov-Bartholdy L, Holst JJ \& Trahair JF. Gastrin release in the fetal lamb in response to luminal infusion of amniotic fluid, milk or GRP. Regulatory Peptides 1996 64167.

27 Guilloteau P, Le Huerou-Luron I, Le Drean G, Gestin M, PhilouzeRome V, Artiaga A et al. Gut regulatory peptide levels in bovine fetuses and their dams between the 3rd and 9th months of gestation. Biology of the Neonate 199874 430-438.

28 Pritchard JA. Fetal swallowing and amniotic fluid volume. Obstetrics and Gynecology 196628 606-610.

29 Reichlin S. Somatostatin. New England Journal of Medicine 1983 309 1495-1501.
30 Liu CD, Balasubramaniam A, Saxton RE, Paiva M \& McFadden DV. Human pancreatic cancer growth is inhibited by peptide YY and BIM-43044-4. Journal of Surgical Research 199558 707-712.

31 Sangild PT, Schmidt MH, Pierzynowski SR \& Greve T. Unresponsiveness of the prenatal pig stomach to GRP and gastrin in utero. Regulatory Peptides 199664168.

32 Hahn von Dorsche H, Reiher H \& Hahn HJ. Phases in the early development of the human islet organ. Anatomischer Anzeiger $198816669-76$.

33 Barz T, von Dorsche HH, Fält K \& Falkmer S. Fluctuations in the mitotic index of the pancreatic parenchymal cells during the various phases of the foetal development of the islets of Langerhans in man. International Journal of Diabetes 19986 $27-34$.

34 Alpert S, Hanahan D \& Teitelman G. Hybrid insulin genes reveal a developmental lineage for pancreatic endocrine cells and imply a relationship with neurons. Cell 198853 295-308.

35 Øster A, Jensen J, Serup P, Galante P, Madsen O \& Larsson L-I. Rat endocrine pancreatic development in relation to two homeobox gene products (Pdx-1 and Nkx 6.1). Journal of Histochemistry and Cytochemistry 199846 707-715.

36 Madsen OD, Jensen J, Blume N, Petersen HV, Lund K, Karlsen C et al. Pancreatic development and maturation of the islet $\mathrm{B}$ cell. Studies of pluripotent islet cultures. European Journal of Biochemistry $1996242435-445$.

37 Edlund H. Transcribing pancreas. Diabetes $1998471817-1823$.

38 Larsson L-I. On the development of the islets of Langerhans. Microscopy Research and Technique 199843 284-291.

Received 8 March 1999

Accepted 24 June 1999 